\title{
Patriotism in Li Bai's Tang Poetry and its Influence on the English World
}

\author{
Ma Yan, Wang Feng
}

\author{
School of Foreign Studies, Yangtze University,Hubei, 434023,PRC China \\ *Corresponding Author
}

\begin{abstract}
As a legendary poet in the history of Chinese literature, Li Bai is undoubtedly considered as one of the symbols of Chinese culture and national spirit. This article tries to explore and explain the patriotism in his poetry regarding Confucianism. The study of Li Bai's patriot passion not only helps translate Li Bai's poetry and Chinese culture but benefits the spread of excellent Chinese spiritual heritage to the whole world.
\end{abstract}

Keywords — Li Bai's poetry, patriotism, national spirit, influence.

\section{INTRODUCTION}

Poetry is one of the best ways for people to know the thoughts and culture of a nation. As one of the typical representatives of Chinese poetry, Tang poetry contains the most precious cultural and spiritual treasures of the Chinese nation, playing an important role in the spread of Chinese culture to the Western world.

Straightforward, unrestrained, wild and optimistic, Li Bai, the most outstanding poet in the Tang Dynasty is known as the "Poetry Immortal" and "Poet Knight-Errant". Rejecting vulgarity, pursuing loftiness, yearning for freedom and transcendentality, the passionate poet wrote poems vigorously in an unconstrained style with rich imagination and varied imageries, and he is hailed as the best representative of the Tang culture and an artistic treasure in Chinese and world literature.

Throughout the ages, the academic circles have spared no effort to explain and interpret Li Bai's poetry. Since the eighteenth century, spanning time and space, Li Bai's poetry has resonated greatly in overseas heterogeneous cultures and civilizations, and he has become the first few Chinese poets whose works were accepted by the Western world and made a great impact on it thereafter. The translation and dissemination of his poetry in the English world symbolize not only the Western spread of Chinese literature, but the wide acceptance of Chinese traditional culture and national spirit in the West.

Patriotism, the ideological foundation and spiritual support of Chinese civilization, is one of the cores of Chinese culture, full of vitality and vigour. It is also a mighty power to unite the Chinese nation as a whole to ensure its survival and continuous development. Throughout the history of ancient Chinese poetry, from the Book of Songs to the poems in the late Qing Dynasty, patriotism has always been an eternal theme in the creation of Chinese poems. Tens of thousands of splendid poems shine the light of patriotism, inspiring Chinese people one generation after another and keeping them in solidarity to safeguard freedom and peace on their motherland. Meanwhile, patriotic poets emerged in large numbers, among whom Li Bai isone of the best representatives of all.

$\mathrm{Li}$ Bai is a typical representative of the Chinese national spirit, and it is not difficult to find out the conveying of Chinese traditional culture in his poems (Han, 2008: 71). In particular, his patriotism, anti-war sentiment, desire for peace and stability in his poems fully reflect the traditional virtues and spiritual strength of the Chinese nation and people. In his poetry, his poetic words as sharp as a sword uncovered corruption and militarism. He appealed passionately in the lines of words for peace, reunification, 
prosperity and stability. While writing, he was never stingy with his love and praise for the beauty of mountains and rivers. His patriotism in the depth of his heart and soul has transcended the boundaries of class, era, society and nation (Gao, 1985: 78).

Li Bai's love for his country and world peace is the common goal pursued by all nations in the world today and is also the national integrity and spirit rooted deeply in the hearts of people across the world. The patriotism in Li Bai's poetry is discussed in the following points: (1)worrying about the country and its people, (2)opposing national division,(3)opposing aggression, (4) praising the magnificence of rivers and mountains, and(5)the influence of Confucianism.

\section{WORRYING ABOUT THE COUNTRY AND ITS PEOPLE}

Li Bai showed his deep concern about the fate of the people and the future of the Tang Dynasty when the society was superficially prosperous but deeply stressed and threatened by latent crisesin the Tianbao Era (742-756). He was quite mindful of potential dangers and got prepared to assume responsibility to serve his country and people. He experienced the flourishing period of the Tang Dynasty in the Zhenguan Era (627-649), as well as its declining in the Tianbao Era (742-756). The government was increasingly corrupted and decaying during the Tianbao Era when Emperor Tang Xuanzong indulged himself in wine, extravagance and immortality regardless of state affairs, bigwigs led a dissipated and luxurious life, and evil governors ruled the country while the loyalsuffered, severely damaging the social economy and intensifying the class conflicts. Eventually, the Tang Dynasty was beset with problems and dangers. In face of the crisis, Li Bai ruthlessly criticized and exposed the social darkness and political corruption of the Tang Dynasty. At the same time, he expressed his concern about his country in many of his poems.

His fifty-nine "Ancient Wind" poems, most of which were written in this period, involve topics such asopinions on poems, revelations of reality, history, gratefulness and lament. He expressed his dissatisfaction with social reality in his poems, and one-third of them are the direct exposure and denouncement of the political corruption, social decline, domestic conflicts and foreign wars of that time, which is an excellent demonstration of his patriotism, for example,

"Ancient Wind No. 46" states:

One hundred and forty years have passed since the founding of Tang, the land growing in prosperity and strength; above the palace a Five Phoenix Tower reared into the mist, the Ching, Wei and Lo rivers joining below; the Imperial court all powerful, glittered in its brilliance; around the palace, young gallants gambled with fighting cocks, or played ball beside majestic buildings, proud, and cocksure were those, thinking all under heaven was theirs to sport with, that their power would be ever lasting, not realizing that when such is lost, they would be discarded.

Yang Hsiung of Han was able, but had to be content with writing his work on philosophy in secret.

(Alley, 1980: 80)

In this poem, the poet showed his contempt to the corrupted ruling class and decisively set a line with them after making a comparison between the past and present of the Tang Dynasty:the outward heyday and the inward peril. In "Ancient Wind No. 18", he wrote "Night and day are given over to pleasure, / And they think it will last a thousand"(Pound, 1914: 15) to criticize Emperor Tang Xuanzong's obsession with singing, dancing and sensual pleasures without caring about state affairs.

In "Ancient Wind No. 53", he bitterly condemned the evil governors' ruling of the government and their sinister plot to overthrow the emperor in the following lines:

In Chao the Prime Minister and the army leader fought, while in Tsin six powerful families intrigued against 
each other, all struggling to gain

power; the Prime Minister of

Chi in the Spring and Autumn Period

played for popularity with the people,

but then killed the Duke his master,

taking the state for his own poste. (Alley, 1980: 139)

Li Bai showed his compassion and praise for the working peopleand exposed the darkness of social politics and the tyranny of the ruling class. He alsoexpressed his deep sympathy for ordinary people and his concern about their miserable life in "And the white bones were piled up in hills-Ah, what had they done- the innocent people?"(Obata, 1922: 175).

The brutality of burning, killing and looting in the An Shi Rebellion left bleakness and unrest to Sanchuan where life was impossible, and people had to flee southward. "In North Fight", he bitterly criticized the crimes of the rebellious troops in the lines "We press forward with no knowledge of when we shall return; / We look back, thinking of our former home."(Ayscough and Lowell, 1921: 22), describing a tragic scene and the sad mood of the people who abandoned their homes and exiled.

Yelling at the sky, he expressed his deep sorrow for the people in the war in the last two lines of the poem "Grieving and lamenting in the midst of ice and snow; / Groaning aloud, with our bowels rent asunder" (Ayscough and Lowell, 1921: 23)

When seeing the trackers laboured to carry hugeboulders for the governmentin dry and rainless days, he could not help writing in pitiful and sympathetic words in "To the Tune of Ting Tu Hu":

the tow path pullers sing songs

together, but their hearts were

full of tears; then we came to a place

where ten thousand peasants hewed out

blocks of stone, but had no way

to get them down to the riverside

just staring at them piled high,

then hiding their faces as they wept.
(Alley, 1980:34)

$\mathrm{Li}$ Bai's love for the working people is also manifested in his praise of them.In "The furnace fire lights up earth and sky, / Red sparks fly pell-mell into the purple sky" in "Song of Qiupu No.14" (Wen Shu, 1989: 92), a hive of activity with everyone in full swing is vividly presented. His description of the innocent and good life of female water-chestnuts pickers is found in such lines as "In the clean green water--the shimmering moon; / In the moonlight--white herons flying" in "Autumn River Song"(Ayscough \& Lowell, 1921: 67), vividly presenting a desirable picture of a happy life.

\section{OPPOSING NATIONAL DIVISION}

Li Bai resolutely opposed the An Shi Rebellion threatening the national unity, which stems from his desire for peace, national stability and unity.The An Shi Rebellion caused a catastrophic disaster to the country and its people, the Tang dynasty being collapsed from a prosperous and glorious empire into a shaky and shattered mess, and peoplewere living in desperation and a dark abyss of misery.

Splitting apart inevitably undermined the unity and solidarity of the nation, hindered the development of its productivity and society, and exacerbated people's sufferings.With incomparable hatred and strong complaint, Li Bai condemned the rebels for bringing a catastrophe to the nation and the people. His concern about the future of the country and his tears shed for the people who suffered greatly are well expressed in his poems.He revealed the sinister nature of the An Shi Rebellion army who were beasts in human dress and exposed their criminal acts of killing innocents in the sharply contrastive lines in "Ancient Wind No. 19":

everywhere could be seen looting

armies, which took Loyang, creating

chaos and madness with blood

flowing everywhere; like animals of prey

rebel army men made into officials

With caps and robes to match.

(Alley, 1980: 138) 
Through the lines, he demonstrated his firm resolution and strong belief to eradicate the rebels and quell the civil strife for national unity.

\section{OPPOSING AGGRESSION}

In the last years of Tianbao, some large-scale foreign aggression wars and frontier expansion for years waged by the Tang government destroyed the good-neighbourly and friendly relations with the surrounding countries and hindered the development of the country, leading to sharp social conflicts and crises. The poet wrote poems, on the one hand, to oppose the government's indulgence in militarism and foreign aggression, on the other hand, to describe the tragic scenes ofunjust wars, as in"Men die in the field, slashing sword to sward; / The horses of the conquered neigh piteously to Heaven" ("Fighting South of the Ramparts")(Waley, 1950: 35) . "Bones white with a thousand frosts, / High heaps, covered with trees and grass"("Lament of the Frontier Guard")(Pound, 1915: 16).

Li Bai's poetic thoughts have had a certain influence on American poet Ezra Pound in terms of his poetry writing and translation because of their similar personal experiences and frustrations.It can be said that Pound found his inspiration in Li Bai' poetry and inherited Li Bai's ideas, which can be found in their complaint against wars.In April 1915, Pound published Cathy in which 19 ancient Chinese poems with Li Bai's were translated, highlighting the theme of war, separation, travel, nostalgia and disillusionment.The first poem translated in his book is the first anti-war poem in history "Song of the Bowmen of Shu" from The Book of Songs, some lines of which were translated as:

We come back in the snow,

We go slowly, we are hungry and thirsty,

Our mind is full of sorrow, who will know of our grief?

(Pound, 1915:6)

In the poetic lines, Li Bai fully expressed the soldiers' deep resentment against war, their agony of anxiety and homesickness.Pound thought that Li Bai's anti-war poems not only uncovered the cruelty of war but also truly reflected the miserable life of the Western peoplein the first World War who suffered from exile, pains, and displacement. The critical realism of Li Bai's poems resonating with the hearts of American people, Cathy received wide praise in the United States.

\section{PRAISING THE MAGNIFICENCE OF RIVERS AND MOUNTAINS}

Traveling around famous mountains throughout his life, he sang the mountains, lakes and scenic spots of his motherland in his poems.He depicted the majesty of waterfalls at Mount Lushan as "Down it cascades a sheer three thousand feet- / As if the Silver River were falling from Heaven!"("The Waterfall in Mount Lu from Afar")(Xu Yuanchong, 2007: 15); the treacherous Yangtze River is found in such lines as:

"The savage wind blows as if it would overturn the Heaven's Gate Mountains

The white waves are as high as the high rooms in the Temple of Wa Kuan."...

"When the Sea Demon passes by, a vicious wind curves back.

The waves beat open the rock wall of the Gate of Heaven."

("The Crosswise River")

(Ayscough\& Lowell, 1921: 26);

The spectacular sights of the Tianmen Mountains and Yangtze River are presented in

"Breaking Mount Heaven's Gate, the great River rolls through,

Its east-flowing green billows, hurled back here, turn north;

From the two river banks thrust out the mountains blue,

Leaving the sun behind, a lonely sail comes forth."

("Mount Heaven's Gate Viewed from Afar")(Xu Yuanchong, 2007: 19)

Li Bai's love for mountains is also found in "We are not tired, the Peak and I, / Nor I of him, nor he of me." ("Sitting Alone in Face of Peak Jingting')(Xu Yuanchong, 2007: 177). His description of the Yellow River is found in such eternal lines as:

"Do you not see the waters of Yellow River coming down from Heaven? 
They rush with an incredible speed to the sea, and they never turn and come back again"("Drinking Song")

( Ayscough\& Lowell, 1921: 58)

"The Luteous River coming from the West

Doth break forth at the foot of Mount Kunlun

To roar for thousands of $l i$,

And dash' gainst the Gate of Dragon"

("Goodman, Cross Ye Not the River")(Sun, 2007: 133)

From a unique aesthetic perspective, Li Bai depicted in his words pictures of spectacular and magnificent landscapes of multifarious styles, igniting the aesthetic pursuit of the generations after him. In his poetry, he pinned his ambitions and patriotic sentiments on his praises for mountains and rivers to build a magnificent and ideal homeland transcending reality.Owen(1981: 114) said that "Originally associated with Ssu-ma Hsiang-ju, such a lofty conception of poetry and the poet was to become an essential part of $\mathrm{Li}$ Po's self-image".Mair commented that Li Bai's poems "are full of the romantic and the fantastic: he had a unique ability to conceive and execute grand visions" (1994:198).

\section{THE INFLUENCE OF CONFUCIANISM}

Ancient Chinese poets were usually under the influence of Confucianism, Taoism and Buddhism, which are in harmony and interactwith one another.In particular, the Confucian "benevolence" as the "supreme" personality of gentlemen set the overall personality norms for the ancient Chinese literati to take the serving of their country as their own responsibility( $\mathrm{Li}, 2005: 91)$.Confucianism represents the mainstream value of traditional Chinese culture. The core of Confucianism is orthodoxy which is the origin of patriotism and the root of the Chinese nation's spirit. Deeply influenced by Confucianism, Li Bai, in his poems, conveyed Confucian ideology through which the value of his life is seen.

Benevolence, the core moral appeal and standard of Confucianism, occupies a very important position in the traditional Chinese system of Thought of Ren (benevolence)(Li, 2015: 180). The concept of "benevolence" in Confucianism endowed Li Bai's poems with love and loftiness reflected in the affection for one's kin, benevolence to others, love for one's country and care for everything.

Li Bai had an active attitude to the world but never foolishly and blindly followed the monarch. He struggled with the dark forces and was concerned about the country and its people. His patriotism is praiseworthy and endowshis poetry with strong moral integrity and unyieldingness distinct from others.His political ambitions to rejuvenate and stabilize a country, to benefit all the people in the world and to make achievementsreflect the Confucian ideal of "helping the folks, stabilizing the country".

Confucianism has a profound influence on Pound who believes that the "benevolence" of Confucianism is not only a Chinese historical experiencebut also a guiding principle to save the Western culture and a driving force for American rejuvenation.His literary works often took the oriental culture represented by Chinese Confucianism as the spiritual reference and the poet's creation source. He translated Chinese poetry and Confucian classics, promoting the Western's understanding of Chinese culture(Nong,2011:57).

\section{CONCLUSION}

Li Bai's poetry not only has an impact on the world poetry and literaturebut has played a positive role in publicizing national values.As Mair said, "Li Bai is universally recognized as one of the greatest Chinese poets of all time"(1994:198).Arthur Waley wrote in his book The Poetry and Career of Li Pothat "As a result of two Wars that have devasted the Worldmen and women everywhere feel a twofold need. We need a deeper understanding and appreciation of other peoples and their civilizations, especially their moral and spiritual achievements"(Waley, 1950:vii).

Therefore, the value of culture and spirit in Li Bai's poetry is playing a critical role in the influence of Chinese civilization on the West.It can be seen that the introduction of Li Bai's poetry to the West not only shows his love for the country, the people and mountains and rivers to the Western readersbut also promotes the spread and acceptance of the Confucian benevolence in the English world. 


\section{FUNDING}

This work was supported by the National Social Science Fund of China under Grant [Key Project 17AZD040].

\section{REFERENCES}

[1] Alley, Rewi. Li Pai: 200 Selected Poems. Hongkong: C \& C Joint Printing Co., (H.K.) Ltd. 1980.

[2] Ayscough, Florence \&Amy Lowell. FirFlower Tablets. Boston and New York: Houghton Mifflin Company. Cambridge : The Riverside Press, 1921.

[3] Gao, Ruixue, Patriotism in the Spirit of Opposing Dignitaries in Li Bai's Poems. Journal of Southwest Minzu University, 1985(01): 78-82.

[4] Han, Liewen, Moon, Wine and National Spirit in Li Bai's Poems. Journal of Chengdu University (Social Sciences), 2008(02): 68-71.

[5] Hou, Dongsheng.Patriotism in Confucianism. Theory Research. 2015(18): 235-237.

[6] Li, Ping. The Release of Taoist Holy Spirit of Politic Wisdom-Psychological Interpretation of Taoist Culture in Li Bai' s Poems. Journal of Liaoning Normal University (Social Science Edition). 2005(01):91-93.

[7] Li, Tefu, English Translation of Tu Fu's Poems and the Overseas Introduction of Chinese Culture. Forum on Chinese Culture. 2015 (5), 180-183.

[8] Mair, Victor. H. (ed). The Columbia Anthology of Traditional Chinese Literature. New York: Columbia University Press, 1994.

[9] Nong, Jia, Wei Hongfa, On the Influence of Confucianism on Ezra Pound. Journal of Anhui University of Technology (Social Science), 2011 (6), 57-58.

[10] Obata, Shigeyoshi. The Works of Li Po. New York: E.P. Dutton, 1922.

[11] Owen, Stephen. The Great Age of Chinese Poetry: The High $T^{\prime}$ ang. New Haven: Yale University Press, 1981.

[12] Pound, Ezra, Cathay. London: Elkin Mathews, 1915.

[13] Sun, Dayu. An Anthology of the Tang Dynasty Poetry. Shanghai: Shanghai Foreign Language Education Press, 2007.

[14] Waley, Arthur. The Poetry and Career of Li Po. London: Allen \& Unwin, 1950.

[15] Wen, Shu. Selected English Translations of Chinese Poems and $\mathrm{Ci}$ Poems. Beijing: Foreign Language Teaching and
Research Press, 1989.

[16] Wong, Siu-kit, Huang Zhaojie.The Genius of Li Po. Hong Kong: Centre of Asian Studies, University of Hong Kong, 1974.

[17] Xu, Yuanchong. Selected Poems of Li Bai. Changsha: Hunan People's Publishing House, 2007. 